\title{
Analysis of the Yu Ebao and Its Impact on the Financial Sector
}

\author{
Xiaojuan Zhang ${ }^{1}$ \\ ${ }^{1}$ School of Management, Shanghai University Of Engineering Science, Shanghai, China \\ Correspondence: Xiaojuan Zhang, Shanghai University Of Engineering Science, Shanghai, China. Tel: \\ 86-150-2656-0853. E-mail: 834624342@qq.com
}

Received: May 20, 2014 Accepted: June 6, $2014 \quad$ Online Published: June 12, 2014

doi:10.5430/wjss.v1n2p78 URL: http://dx.doi.org/10.5430/wjss.v1n2p78

\begin{abstract}
In June 13, 2013, Alipay combined Celestial fund jointly launched the Yu Ebao, Yu Ebao is a kind of financial value-added service on Alipay platform, users can transfer balance from Alipay account to Yu Ebao, is recognized that is seen as a particular fund to buy financial products, to obtain a relatively high income, but also the fund in $\mathrm{Yu}$ Ebao is readily available for online shopping and Alipay transfer and so on.This simple Internet financial model is highly welcomed in China because of its more than 10 times higher rates compared with the Saving Bank interest rates. According to China Securities News, Yu Ebao has attracted more than 400 billion with more than 61 million users by March 15, 2014. This explosive growth has caused a hot topic in society. The paper analyzes what is $\mathrm{Yu}$ Ebao, the reason why Yu Ebao could develop so rapidly and its potentials, the advantages and disadvantages of Yu Ebao, and whether it will be a powerful competitor to the traditional financial sector will be discussed as well.
\end{abstract}

Keywords: Yu Ebao, financial sector, Alipay, Celestica Fund

\section{Analysis of the Industry Background}

In recent years, with the rapid development of information technology and electronic commerce in progress, the Internet financial is growing at an unstoppable trend which is changing our lives, affecting our spending habits, lifestyle, and show an expanding market space and potential. Yu Ebao is in this environment came into being, and the fierceness also allows us to witness its development potential.

\subsection{Alibaba Accumulated Years of Financial Management Experience to Explore}

Yu Ebao has Alibaba this powerful backing.Alibaba is the carrier of domestic e-commerce, has built a powerful e-commerce platform, won a great commercial reputation, but also have large data resources, through the Yu Ebao sales Monetary Fund is the touchstone Alibaba into the financial sector, is one of the development strategy of "do platform, do financial, make data" the three step, the market prospects is broad. Alibaba has been exploring new financial model, Paypal from May 2012 to get the funds to pay a license issued by the Commission, have been thinking about how to pay by way of the Internet to the user, to the entire fund industry to bring some value.And Alibaba Group is introduced in the Yu Ebao at cost a lot of manpower and financial resources, gathering high-tech talent, innovative financial products.

\subsection{Alipay Huge Customer Base and Rich Platform Resources}

The rapid development of Internet financial in modern society, financial products is very high degree of homogeneity, copy imitation costs relatively low, so for the scale of a financial product, the development of the most important factor is channel and platform competition. The domestic market share of Alipay as the highest third-party payment platform, mainly due to Taobao and Alibaba's online shopping, with over 800 million registered users, the average daily turnover of over 4.5 billion yuan, assuming that the turnaround time for each transaction 4 days, the average idle funds in Alipay reached around 20 billion. The treasure to pay a huge customer base and feel the balance of funds precipitated treasure give tremendous prospects for development.

\subsection{Fund Industry Products and Marketing Model Need to Overcome}

After the fund industry experienced a bull market, began to face the difficult situation of development, a large proportion of customer loss, brain drain, investment management capacity declined, the product quality decreased. At the same time, fund marketing difficult collapsed, the fund is currently more than $80 \%$ of sales by banks, fund 
distribution system which is under the auspices of the Bank over the past decade, under this system of fund companies to improve the marketing costs, the cost of customer choice, restricted the fund industry innovation. Yu Ebao is essentially a kind of monetary funds, but in the convenience is superior than the common currency fund. Therefore, both has the use Alipay platform habit and often buy monetary fund clients will be the Yu Ebao's potential customers.

\subsection{Tolerant Attitude of the Government to Pprotect the Yu Ebao of the Internet Financial Relatively Stable Development Platform}

Since the new Government came to power, the implementation of a series of policies and measures of financial regulation aimed at controlling market risk, while also providing an opportunity for the financial innovation in the national policy to encourage financial innovation, the number of financial companies have begun to develop and Internet, e-commerce combined with financial products. Yu Ebao is the treasure of Alipay and Tianhong Fund jointly launched a new financial products.

\subsection{Yu Ebao Low Threshold to Adapt to Modern People's Consumption Concept of Financial Management}

We found that active in Alipay platform is 80,90 customer groups ,most of them do not actually what most people experience in financial management, but not much spare cash on hand, it is impossible to find specialized financial institutions to finance. Yu Ebao this financial product from the user point of view, a small amount of money can also be financial, and do not set the threshold, the fund of funds direct to the Paypal website system in the front, one yuan to buy, users buy very convenient. So that the Yu Ebao has a huge customer base in the short term, after the rapid development of on-line.

\section{Yu Ebao Product Overview}

\subsection{To Understand the Yu Ebao, We Must Understand Monetary Fund}

Monetary Fund is a good place for personal money selection, run by fund managers, an open-end funds in escrow fund of funds, to invest in specialized risk-free money market instruments, different from other types of open-end funds, with high security, high liquidity, stable profitability. Monetary fund trading does not require fees, income is generally higher than one-year bank deposit 3\%, and much higher than the one-year deposit flexibility to redeem up to 2-3 working days, will not delay the money, have a "quasi-saving" feature.

Celestica Fund was established in November 2004 with a registered capital of 180 million, was approved by the Commission of a national public fund management company, currently has raised funds, eligibility and other specific client asset management business, is now the only money fund balances provide a treasure, offering a customized open-end fund-Celestica Zenglibao. The fund is a money market fund that invests primarily in bonds, bank deposits and other revenue agreements stable, low risk financial instruments, securities investment funds in low-risk species.

\subsection{The Definition of Yu Ebao}

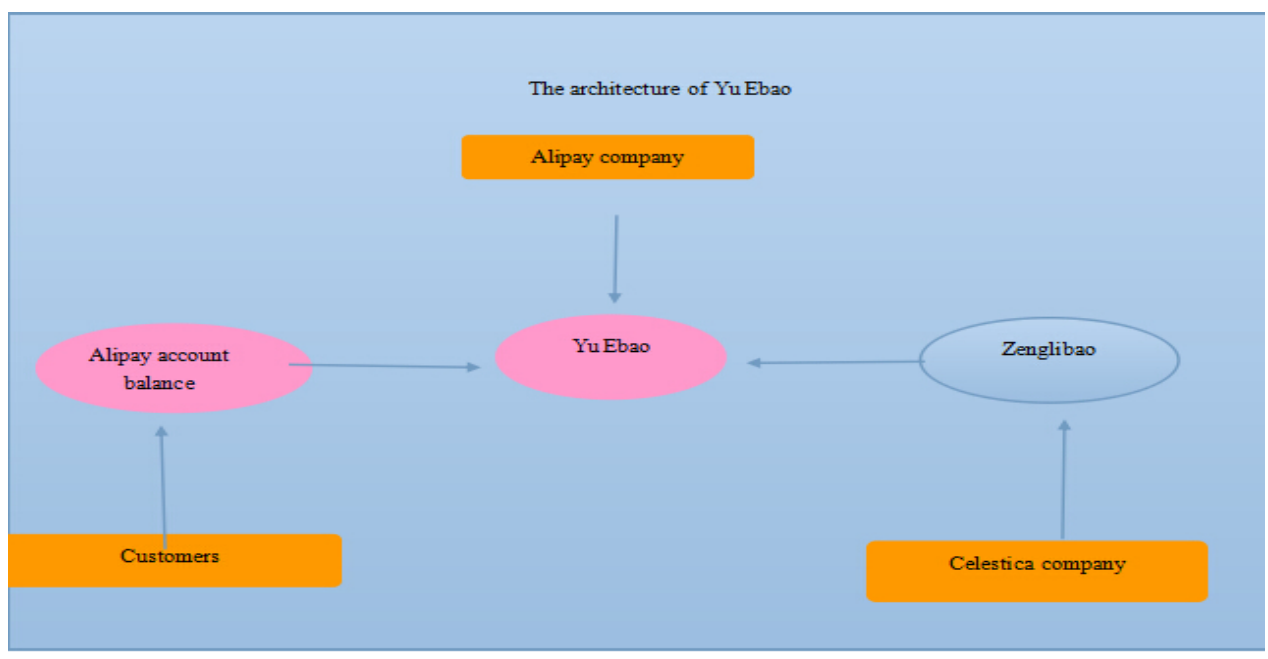

Figure 1. 
Yu Ebao is a third-party payment platform combined Celestica launched a fund balance of value-added service, Alipay users transfer funds to the account of the Yu Ebao can get benefits,but is actually the name of an offer to purchase by Celestica fund "Zenglibao" monetary fund.Users deposited in Yu Ebao funds can get higher than bank deposit interest income over the same period of risk, also can be used Alipay account consumption. That is to say users transfer funds to the Yu Ebao, the money is not actually transferred to Alipay account, but to make a purchase monetary fund,the funds transferred from the Yu Ebao or the Yu Ebao supported monetary fund to pay for shopping, it is equivalent redemption monetary Fund.

There are three main participants directly in the design in Yu Ebao, respectively Alipay companies, fund companies (currently only Celestica fund company) and Alipay customers.Among them, the company launched Alipay payment and value-added features of both Yu Ebao products are traded fund customers and third-party settlement providers resource tools; Celestica fund companies launch products Zenglibao, and the Yu Ebao embedded in the fund sellers; Alipay customers through Alipay account transfer balance to the Yu Ebao, to achieve buying and holding Zenglibao Fund, is the fund buyers.

Through a series of institutional arrangements, the Yu Ebao ultimately realize the Alipay company, fund companies and Alipay customers tripartite win.For Alipay company, fund companies offer funds direct to the customer and billing platform, not only prohibits third-party payment companies can circumvent fund products regulatory agency, and can be a modest reduction in excess reserves reserves and capital adequacy pressure, and can get some the management fee income; for fund companies, not only can immediately open up a new sales channels, increase the size of the fund sales, but Alibaba can make full use of a wide range of stable customer resources to develop innovative business and enhance capacity for sustainable development; for users, while ensuring consumer payment premise, you can increase the value of money.

\subsection{Yu'E Bao's Innovation}

\subsubsection{Technological Innovations}

Yu Ebao can achieve financial from fund account as automatic redemption for shopping. Yu Ebao integrated immediate payment $(\mathrm{T}+0)$ into the customer premises consumption, convenient for our customers while providing added value accounts, did not affect the customer experience of all payments, Alipay customers can use Yu Ebao's fund in Taobao station in real-time payment or transfer to others Alipay account. Alipay in order to avoid regulatory risk ,so in the design of the Yu Ebao, they put the fund behavior is defined as direct sales, and in strict accordance with the design of business processes depend on direct sales, trading platform Alipay charge management fees, thus successfully evade the regulatory risk.

\subsubsection{Innovative Ways to Raise Issues}

The Yu Ebao use of the "long tail", the long tail theory is a new theory of the rise of the Internet age, presented by American Chris Anderson. The so-called long tail theory refers to, when the commodity storage circulation shows the location and the channel wide enough, a sharp decline in the cost of production of commodity so that individuals can be produced, and the cost of goods sold decreases sharply, almost any past seemingly demand extremely low product, as long as there is to sell, someone will buy it. These needs and not high sales volume products occupy the common market share, compared with the mainstream products market share, even greater. Furthermore previous investment and financing channels for high net worth and there are some people credit guarantees, since 2010, Alibaba launched to provide small businesses loans under $\$ 500,000$, "Ali small loan" to ease their financing difficulties, this time Alibaba has launched a new investment and financing mode for ordinary users to use a very small amount of money they can afford it.

\subsubsection{The Innovation of Marketing Mode}

Yu Ebao in the marketing channels to create a large fund companies in the electricity business platform for direct fund model .Yu Ebao in the Internet marketing process to create a one-stop sales model. In order to give customers an excellent shopping experience, try transforming every Alipay customers. Celestica fund and Alipay system in the background provide a lot of technical support for the Yu Ebao, the first increase in Zenglibao convenient "one-click to open an account" process. Customers will transfer money into Yu Ebao, and increased profits on the immediate purchase of Zenglibao, and if customers choose to transfer funds out of Yu Ebao or use Yu Ebao's funds to pay for shopping, is equivalent of the redemption by Zenglibao fund shares. All process operations with immediate effect, and very convenient. Yu Ebao in the marketing strategy around "to enhance customer value as the center" for innovation. Yu Ebao in marketing highlights the purchase by Zenglibao fund threshold low, only one yuan can buy, is the lowest threshold for all funds in a fund. Every yuan in customers' Yu Ebao, they can add value every day, many 
customers through the Yu Ebao of the first attempts to finance life, enjoy a sense of charm and value-added which"public finance" brings. Yu Ebao nuanced around" to enhance customer value-centric" innovation, has been highly recognized by our customers, so that Alipay deposit continue to flow in excess reserves Yu Ebao.

\section{The Advantage of Yu Ebao}

Yu Ebao since the advent of which has been widespread concern in the community, considered following the Alipay after another "change" the Internet financial history events. This high yield, new business at any time can realize the consumer payments, hit with the users, only in the line after 18 days created daily customer increment of about 140000 households, the average daily incremental funds about 300 million yuan development miracle. Yu Ebao is so popular, what are the obvious advantages.

\subsection{Operation Is Simple}

Yu Ebao service is that fund company's direct sales system built into the fund Alipay site, users put money into Yu Ebao, actually make a purchase monetary fund, the corresponding funds managed by fund companies, nor the income of Yu Ebao "interest ", but users buy monetary fund revenues, if the user choose the Yu Ebao of funds to pay for shopping, is equivalent to the redemption monetary fund. The entire process just to Alipay, cash payment or shopping as simple. Compared to bank savings and fund,Yu Ebao background is visible and gain real-time grasp the situation.

\subsection{No Restrictions on the Minimum Purchase Amount, Low Threshold}

Yu Ebao is no limit to the minimum purchase amount of the user, Yu Ebao's goal is to let the pocket money can get value-added opportunities, let the user even one or two yuan, one hundred or two hundred yuan can enjoy financial happiness. Celestica Zenglibao fund is currently the lowest rates, the minimum threshold, the operation of one of the most convenient monetary fund. The common currency fund management fee rate is generally $0.33 \%$, trustee fee is generally $0.1 \%$, while increasing Zenglibao one yuan purchase, management rate of only $0.3 \%$, trustee fee is $0.08 \%$.

\subsection{High-yield, Flexible}

Compared with the general "money begets money" financial services, The Yu Ebao's greater advantage is that it can not only provide high income, but also fully support online shopping consumer, Alipay transfers almost all of Alipay function, which means that the funds in the Yu Ebao keep one hand in increasing value, on the other hand can be used at any time of consumption. At the same time, Celestica Zenglibao monetary fund support the $\mathrm{T}+0$ real-time redemption, Alipay transfer of funds in the Yu Ebao you can always turn out to Alipay, withdrawals can also be directly to bank cards.

\subsection{Large-scale Users}

Yu Ebao has the country's largest third-party payment platform Alipay as a strong support. Most of Yu Ebao's clients are Alipay users, huge user groups destined for Ali as long as any to launch a fresh, interesting product will cause the attention of the outside world and sensation, but also means that there is a huge customer base, capital reserves and higher customer loyalty. Alipay has over 800 million registered users, the average daily turnover over 20 billion yuan. If half of the users spend 100 yuan to buy the fund, it can create 40 billion of fund sales.

\subsection{Comparison of the Bank Financial Products Have the Advantage of}

1. Alipay previously idle funds which could not gain, so most of them back to the original bank account, but now not only hopeless flow of capital, but also absorb a large number of the bank account into Yu Ebao.

2. Yu Ebao is extremely flexible and its business opening is convenient, people can always redeem or withdraw cash to pay for consumption, while demand deposits and highly liquid investments with features, easy to use, and yet allows customers to get higher returns, this completely done to the customer as the center.

3. Although there is no characteristics in product innovation of Yu Ebao, but Alipay has a strong channel advantage, client stickiness and data advantage; regulatory level, the government level for the Alipay such exploration and challenge, but also show significant encouragement and support.

4. If two different bank accounts transfer each other, can use the Yu Ebao fee free, convenient and easy.

5. The costs related to fund sales are lower than the bank agency, a large number of potential customer resources is a great temptation for fund companies. 


\section{The Disadvantage of Yu Ebao}

Yu Ebao gives users a lot of benefits, sought by the public users, but in fact the Yu Ebao hidden certain risks. Users should not blindly rely on the Yu Ebao, as a pure product revenue for its.

\subsection{Liquidity Risk}

Yu Ebao's profits is related to Monetary Fund, but Monetary Fund returns is unstable that fluctuates with economic and market conditions, so Yu Ebao may occur even large fluctuations in losses. While Monetary Fund is the product of all fund products which risk is relatively low, generally used for investment bonds, bank deposits and other safe, stable income financial instruments, but as a fund product, like banks and securities firms selling funds, returns associated with risk. Despite the currency monetary fund market performance is steady, but as a kind of investment, it may be risky, even if the probability is one ten thousandth or one hundred thousandth; and once purchased Monetary Fund revenue goes wrong, the user of funds will suffer loss. This requires high security customers obviously do not have much appeal.

\subsection{Internet Security Issues}

Yu Ebao is fully operational on the Internet, the potential risk of network itself can not be eradicated, Yu Ebao's profits risk and network technology risk coexist, with many network uncontrollable factors, the Yu Ebao is not no risk at all. This means the account has the risk of being stolen, since the Yu Ebao public, many people had been reflected the problem that the fund in Yu Ebao was stolen, the amount ranging from 500 to 100,000 yuan, it surely reflects Yu Ebao has network vulnerabilities. Users select Taobao account login, due to defects in application design, may lead to hackers crack users Taobao account, thereby threatening the Alipay and Yu Ebao's safe. It also makes rational customers that don't make large funds to buy financial products through the Yu Ebao.

\subsection{Financial Regulatory Risks}

According to the central bank on the third-party payment platform management regulations, Alipay balance can purchase agreement deposits, but there is no clear provisions on whether to buy the fund. Although the Alipay obtained funds to pay license in 2012 May, but did not get the fund sales license. Due to regulatory restrictions, the third-party payment companies can not sale fund, so nominally, this IMF funds by Celestica direct sales, the role of Alipay in the whole chain is only just payment. With the help of Celestica fund,Yu Ebao can achieve the function of selling funds, but this approach is playing edge ball. From a regulatory perspective, Yu Ebao is not legal; once the regulatory authorities launched an attack, the Yu Ebao may be halted.

\subsection{Endanger the Bank's Interest, May Be Suppressed}

Alipay has been unable to pay interest to the user, this is an important factor of limiting their capital scale, Alipay launched $\mathrm{Yu}$ Ebao in the hope that through monetary fund higher income than bank to attract more customers to transfer funds from bank to Alipay. This means that Alipay has tired like bank cards, "deposit-taking" ability to compete and form a positive relationship with the bank. Financial products have high similarity, and copying costs is relatively low, the appearance of Yu Ebao is a warning for banking and finance industry to a certain extent, banking and finance industry will certainly make the appropriate preparations, and actively improve the existing innovative mechanisms; currently the bank's online payment platform have been more perfect, just follow the Alipay platform to strengthen cooperation with monetary fund companies, banks will be able to deliver better financial products to meet the challenges from Alipay. If a huge amount of money in Yu Ebao is a big fear for the banking, which relies on bank survival may be blocked.

\subsection{The Lack of Financial Professionals}

Alibaba started doing e-commerce, companies lack the financial reserves of high-quality personnel, which will affect the development of forward-looking business strategy and specific operations professional. But at present, most fund companies have adopted a wait-and-see attitude to Yu Ebao, because frequent trading of Alipay causes uncertainty about the size of the fund, also has some relevant market risks, policy uncertainty, so Alibaba also lacks a powerful, sophisticated company in the fund management to manage the fund.

\subsection{Risk Scale}

According to the Yu Ebao's official data can be seen, in the Yu Ebao just established more than 10 days, the fund size has far exceeded market expectations. The fund in Yu Ebao can be spending online and transfer an any time, but the IMF will settle accounts with Yu Ebao after IMF daily return closing, this period is that Alipay undertakes credit disbursements for Monetary Fund, if monetary fund can not be settled on time with Alipay, Alipay will face the risk of large capital deficit. According to the growth of electronic commerce scale, the future growth of Yu Ebao's capital 
within a few hundred million to billion is not impossible. Once the fund grown to 100 billion of Yu Ebao, Alipay will be difficult to face the risk of liquidity. However, from the perspective of historical experience of Monetary Fund, the too small size of monetary fund has liquidity risk, but the size is too big, there will also have no enough money for market instruments to choose from, then the Yu Ebao's returns are also likely to decline.

\section{Effect of Yu Ebao on China's Financial Industry}

Yu Ebao since its introduction, has always been a hot topic of discussion in the financial industry. When we enjoy the happiness of benefits which Yu Ebao brings us, at the same time we should not ignore the impact of Yu Ebao brings to the traditional financial sector. The impact of Yu Ebao on the traditional financial sector is divided into the banking industry and fund industry.

\subsection{The Impact on the Banking Sector}

$\mathrm{Yu}$ Ebao is a great attempt and innovation in China financial history, new commercial channels and product advantages would make Yu Ebao has obtained the fast development and rapid growth, an increase from zero to tens of billions, or even billions, but billion development will face enormous challenges and difficulties in the future, growth will slow down. To some extent, the impact on the formation of deposits money, forcing banks to change the current innovative financial mechanisms, and actively explore and try new better products to meet the needs of investors.

\subsubsection{Shunt Part of the Bank Deposits}

Previously the idle funds in Alipay could not gain benefits, so most of them return to the original bank accounts, now not only hopeless of capital flow to the original bank accounts, but also absorb a lot of bank deposits into Yu Ebao. Yu Ebao will attract more idle funds flock to Alipay, inevitably impact on the banking business.

According to the current development momentum of Yu Ebao, a great diversion trend in banking deposit market, which will have a profound impact on small banks under the background of accelerating the interest rate market. If the fund of Celestica fund and Yu Ebao reached 500 billion to 600 billion yuan, it means that the equivalent of a joint-stock bank one year new deposit scale, , if the scale of Yu Ebao reached 800 billion to 1 trillion yuan, it is quite a large bank one year new deposit scale. We should see that an increase in the size of the Yu Ebao, a large part of which may be a decrease in the size of bank deposits, so the high-speed development of the Yu Ebao, will have a profound impact on the development banking business, even impact the debt part of small and medium-sized banks.

5.1.2 To Provide Financial Services for Small Accounts and Help Clients Avoid Risks of Shopping Online Does not Pay Reserve Interest

It is understood that the current users of Yu Ebao are already 80,90, this part of the group generally prefer online shopping, pay attention to the financial management products, and there is a strong consensus to change their own destiny through the Internet. The main users of Alipay is the youth, people born in 1980s accounted for more than 60 percent, their economic accumulation is thin, so they are longing for their small funds stable value-added. Although Alipay's customers were told that Yu Ebao in essence is a kind of financing model, there is a certain risk, but Alipay's customers have high identity for the security and credibility of Alipay, are still willing to put money into Yu Ebao.

Yu Ebao in providing financial services to customers, while the funds turn into Yu Ebao does not affect the use. Customers can use the funds in Yu Ebao at any time within the online shopping and consumption. It is convenient, and do not charge fees, while avoiding the problems of online shopping excess reserves interest. Customers can save a lot of time and money.

\subsubsection{Reduce Intermediate Business Income of the Bank Account}

With the launch of Yu Ebao mode, greatly broadened the fund sales channels, reduce dependence on bank fund distribution business, further shunt the bank fund distribution business. After the third-party platform get a license for fund sales, which has caused a strong impact on bank fund distribution business.

Because of financial products in the market access threshold distribution is generally higher, and the liquidation time is relatively long, plus sometimes the income from bank consignment of financial products is not very satisfactory and the risk is relatively high, so the development of financial products business of bank consignment is not very good.

Yu Ebao makes up all inadequacies of the same type of financial products of the bank, coupled with its convenient and Alipay conversion, making the Yu Ebao compared to the same type of financial products banks favored by 
consumers, in the long run this will cause a certain degree of impact on banking consignment financial products business, reducing this part of the income of the bank.

Yu Ebao opened a third-party payment platform of direct selling funds first, although only a cooperation fund of Zenglibao, but the scale is now already exceeded 10 billion, if Alipay has launched more structural differences of fund products, and plus other third-party payment companies to follow the aggregation effect, the fund distribution business of commercial banks will be seriously challenged.

\subsubsection{Yu Ebao Force the Bank Transformation}

Yu Ebao is a monetary fund, also a more attractive financial product launched by Alipay, it actually plays as a civil power to break the bank in the sale of financial products and even the effect of "deposit-taking" aspects of monopoly, is a new technology, new business model to break monopoly again. Banks should reflect on why they can not launch new financial products like Yu Ebao which has high liquidity, high yield? Can not do, or do not want to do? The appearance of Yu Ebao has once again exposed the bank's profits space.

Yu Ebao launched by Alipay in a greater extent is a beneficial exploration of large data applications and financial innovation. The traditional banking industry needs to guard against is that the development of science and technology, especially the advent of the big data era lowering the threshold for traditional industries. Analysts predict that as Alibaba himself declared, Alibaba do not traditional commercial banks, but to direct towards the era of the Internet financial restructuring of commercial banks is an important direction - an Internet financial assets management platform based on large data. And this trend has aroused great concern in domestic banks.

While Yu Ebao is exploring better development, financial institutions in the banking industry in fact has already started to pay attention the development of Internet finance, and has begun to wrestle Internet financial product innovation and upgrade traditional business.

\subsection{Impact on the Fund Industry}

In addition to the impact of Yu Ebao on China's banking industry, but also for China's fund industry had a certain impact. The most obvious example is Celestica fund due to launch Yu Ebao with Alipay it greatly increased strength. It also illustrates one aspect of the broad prospects for the fund industry, but also for many fund companies is now indicating a direction of development, that is, cooperation with third-party payment platform to direct selling fund products. Of course, the success of Yu Ebao can also see the development direction of financial products, the next step is to continue to reduce the access threshold, to ensure as much as possible to shorten the liquidation time under the premise of higher income.

For fund business enterprises, low risk, easy to understand, standardized monetary fund is undoubtedly more suitable for products. Due to the possibility of loss is very low, so monetary fund company through suitable publicity is relatively easy to make investors more confidence. The Alipay accumulated a huge customer base to Yu Ebao, which in the form of monetary fund is more easily accepted by Alipay customers. Meanwhile, the grafting Alipay payment function, fund is equivalent to have a certain amount of payment function, which is also very important to enhance the attractiveness of monetary fund. In fact, the large-scale development of American monetary fund also benefited from payment function improved.

Although the appearance of Yu Ebao in a certain extent, ignited the hope of fund companies, but the fund sales with mobile Internet achieved rapid development is still awaited. Ultimately, the fund has not yet been recognized by domestic investors and investment adviser chain is not mature are the fundamental factors restricting the fund business. When investors do not trust funds, and there is no one to help investors scientific allocation fund, even though the mobile Internet platform function is more perfect, it does not help to fund sales. Only in the context of improving fund performance and provide investors with an effective fund allocation services, fund business enterprises in the spring will really come.

\section{Conclusion}

By the rapid development of the Internet can be seen, the balance of financial market has great potential, a lot of e-commerce enterprises, fund companies, banks want to profit in which the competition is quite fierce. While the Yu Ebao has a strong of Paypal as a backup, to seize the initiative, the advantages of high yield, convenient and flexible made it in a short time created a large number of fund sales for the fund company. In this case, Alibaba Alipay should be careful to choose fund companies for future cooperation, so as to enrich the corresponding monetary fund of $\mathrm{Yu}$ 
Ebao, to make up for their own business background on the monetary fund operation and the risks do not know much weakness.

\section{References}

Gezi, \& Linjiang. (2013). Yu Ebao--Internet financial showstopper. Posts and Telecom Press, July 5, 2013.

Jiangqinghai, \& Liqingzhi. (2012). How the Yu Ebao will change the bank. China Securities Journal, July 10, 2012.

Lishuxuan. (2013). How to treat the Alipay Yu Ebao. Securities Times, 2013(10).

Qiuxuan. (2013). The huge risk of Yu Ebao. Shanghai Finance and Economics, 2013(07).

Xieping. (2012). Internet financial model research. Finance Research, 2012(12).

Zhaomingchao. (2013). Yu Ebao concept popular in the market. Shanghai Securities News, July 3, 2013.

http://www.thfund.com.cn/

https://financeprod.alipay.com/fund/index.htm 